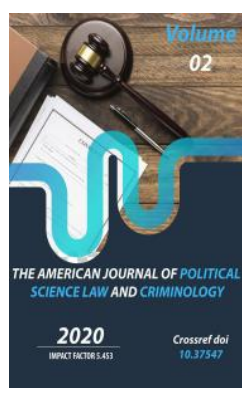

\title{
Invalidity Of A Contract Concluded As A Result Of Improper Use Of Material Rights (Property Rights) And Abuse Of Law
}

\author{
Mamurov Shokhrukh Boboxonovich \\ Independent Researcher At The Tashkent State University Of Law, Uzbekistan
}

Copyright: Original content from this work may be used under the terms of the creative commons attributes 4.0 licence.

\section{ABSTRACT}

This article is aimed invalidity of a contract concluded as a result of improper use of material rights (property rights) and abuse of law. In addition to actions aimed at abuse of property rights constituting a violation, actions that disproportionately violate the rights and legitimate interests of neighbors (the benefit received by the owner, disproportionate to the inconvenience for the neighbor) can also be assessed as abuse. Invalidation of the agreement on the disposal of prohibited property to unscrupulous third parties allows the creditor to bring a claim for the seizure of property from the unscrupulous third party, and in the event of a substantial claim by the plaintiff, to obtain an excuse from the unscrupulous owner. Naturally, a refund request can be combined with a request to invalidate the transaction. At the same time, according to the logic of things, in cases of bad faith of the owner of the prohibited property, it is necessary to invalidate not only the transfer of property, but also the entire contract

\section{KEYWORDS}

Abuse of law, invalidity of a contract, property rights, improper use of material rights, prohibition of abuse.

\section{INTRODUCTION}

Property law, due to its absolute nature, implies that the authorized person exercises his rights independently and sovereignly. In particular, the content of the property right is the ability of the owner to perform any actions that do not contradict the law and do not 
violate the rights and legally protected interests of others. Since the law does not fully define the potentially detrimental interests of others in the exercise of their rights, it is difficult to assess the role of prohibition of abuse and fair behavior in this area.

The owner's ownership right cannot be exercised without taking into account the general principles of civil law. This means that when establishing, exercising and protecting civil rights, in the performance of their duties, participants in civil legal relations must act honestly, not abuse the right (paragraph 5 of Article 9 of the Civil Code) and not profit from their dishonest behavior.

Subjective abuse of property rights means going beyond the exercise of civil rights in the context of the subjective property rights of a participant in property relations when choosing a way to exercise their rights to satisfy their private legal interests.

We also briefly touched on this form of property infringement in the previous paragraph. In this section, we analyze the legal nature of abuse of property rights in good neighborly relations, the most frequent cases of abuse in practice.

Despite the fact that property rights represent an absolute legal relationship between an owner and other persons, the likelihood of a conflict with abuse of property rights is higher primarily among neighbors and participants in common property [1].

Neighborhood law is the most common case of property rights violations. Although good neighborly relations (due to the will and discretion) have not been regulated in detail and clear legal prohibitions have not been established, the interests of the owners of neighboring property should be taken into account by the owner - this follows from paragraph 5 of Article 9 of the Civil Code. A landlord must refrain from unfairly influencing a neighbor's property, even if it is formally legal. For example, he cannot dig deep or dump trash in his lot next to a neighbor's house to damage it. A classic example of such abuse of property rights in neighborly relations is in Gogol's story "How Ivan Ivanovich Argues with Ivan Nikiforovich" in this story, a hated neighbor builds a cattle farm (next to his neighbor) in order to put an end to his insults against his neighbor. The shed, disgusting to Ivan Ivanovich, was very fast: it was built in a day. That is, a neighbor builds a barn only to harm his neighbor, create a disgusting smell and discomfort for him. The claim of the denier brought against the owner as a result of such actions must be qualified and satisfied as an abuse of the right in the form of a complaint. It is clear that the neighbor in this case misused his property and this is prohibited by law [2].

In addition to actions aimed at abuse of property rights constituting a violation, actions that disproportionately violate the rights and legitimate interests of neighbors (the benefit received by the owner, disproportionate to the inconvenience for the neighbor) can also be assessed as abuse. For example, a neighbor (landlord) must temporarily use someone else's land for this repair: after all, you can repair a neighbor's back wall without going into someone else's land.

In addition, the owner should not allow water to drain freely to his site from a neighbor, not interfere with or block the water flow from a neighbor (do not pour soil into a ditch), do not pour soil into his area, do not dig deep in his area, do not build wells so that water does not get into neighboring wells, do not build sewage facilities that pollute the neighboring area [3]. 
Another area where material and legal abuses are common is relations with common property. A classic example is the tendency of a person with less ownership to lie and try to get other owners to buy at a higher price (obstacle, damage).

Often in such cases it is also implied that the use of the dwelling as a whole may be prohibited in relation to the person who owns $1 / 50$ of the dwelling. In theory, the refusal of the "minority owner" to consent to the disposal of the common property can be considered an abuse, even if such refusal has no rational reasons and is a form of personal hostility or extortion.

Can the owner's inaction be regarded as an abuse of the right? While abuse usually requires proactive behavior - action, inaction cannot be ruled out. Even if the law does not impose on the owner of the land plot the obligation to maintain it in proper condition, the owner's inability to take care of his property (to leave it as it is) can be regarded as unfair behavior.

For example, a landowner allowed weeds to grow and invade the land. Neighbors can demand compensation from the homeowner for the damage caused by the spread of the nymph's seed, but this method is practically not legally effective. Therefore, neighbors can hire grass pickers to mow the stem in someone else's area, and reimburse the negligent neighbor. If the defendant objects to this action as an invasion of its territory and objects, the plaintiff can achieve its goal by abusing the right and defending against abuse (the defendant, on the contrary, is denied judicial protection).

The use of disproportionate means of protecting property rights can also be assessed by the court as an abuse of the right and can be the basis for refusing a claim [4]. A typical example of such a disproportionate claim would be a claimant's claim to demolish a nearby device that has infiltrated a piece of land in very small quantities.

The right to conclude a contract is based on the will of the parties and the freedom to conclude a contract (Article 354 of the Civil Code). But in many cases there is no equal opportunity for the parties to conclude a contract. This inequality can be the result of market power, inequality in professionalism and awareness, limited rationality of one of the counterparties, and a number of other factors (for example, agreement to purchase computer equipment, contracts for legal assistance, one party is professional and may enter into an agreement on various unfair terms, while the other party may enter into an unfair contract due to lack of awareness). In the case of clearly unequal bargaining power, the conclusion of a contract excludes the possibility for the weaker party to influence the content of the terms of the contract, avoid concluding a contract on such terms and in some cases understand the terms offered. Ultimately, this opens up the possibility of establishing conditions that are formally legal, but clearly unfair. Such behavior by a strong party may be considered an abuse of freedom of contract under certain circumstances.

Another example is the sale of seized property to an unscrupulous buyer. When the owner sells real estate or other property prohibited by the court to a third party (in this case, it may be known that the seller to the third party violated the prohibition imposed by the court or other authority (for example, the executive body) according to the rules, it may be invalidated.

Invalidation of the agreement on the disposal of prohibited property to unscrupulous third parties allows the creditor to bring a claim for the seizure of property from the unscrupulous third party, and in the event of a substantial 
claim by the plaintiff, to obtain an excuse from the unscrupulous owner. Naturally, a refund request can be combined with a request to invalidate the transaction. At the same time, according to the logic of things, in cases of bad faith of the owner of the prohibited property, it is necessary to invalidate not only the transfer of property, but also the entire contract.

Prohibition (arrest) means the prohibition of the alienation of property in an imperative form by a state body through a public law mechanism [5]. If the owner decides to violate this prohibition, and the buyer intends to purchase the property knowing that it is violating the authorities' decision to prohibit it, then it is illogical and unfair to keep such an agreement in force. Such prohibited activities should not be encouraged by law. Therefore, the recognition of the transaction as invalid is an adequate reaction of law enforcement agencies in the event of alienation of prohibited property.

An example of the prohibition of abuse of power in order to protect a creditor is the intervention of an unscrupulous third party in a contractual relationship. As such, the foregoing examples of foreclosure or foreclosure are also examples of an unfair third party infiltrating the debtor-creditor relationship. However, there is one aspect related to the fact that the debtor entered into procedural relations with the creditor. However, an unfair third party may enter into a foreign liability relationship by entering into an agreement with one of the parties to such a relationship, except in cases of sale of prohibited property or foreclosure of liquid property (the purpose of which is to make it impossible to enforce in the event of a court decision) can happen. For example, in cases where the property promised by the seller to another buyer is occupied by a third party, a situation where a property occupied by an option for a specific buyer is occupied by a third party [6].

In the aforementioned cases of fraudulent penetration, as well as in cases of out-ofcompetition dispute (penetration), a third party (infringing the rights) enters into a transaction with the debtor with obvious dishonest behavior, which leads to an inevitable violation of the debtor's relative rights (especially on the eve of bankruptcy on sale).

In the cases described above, the third party (the attacker) is clearly dishonest and clearly knows (or may not know) that by entering into a deal, it incites the other party to violate the contractual rights of its creditor in its own interests. This paves the way for canceling such an agreement. Consideration could be given to invalidating the transaction with an unscrupulous third party.

Unfair interference in the relations of others can take place not only in cases where the debtor knowingly owes a debt to the creditor by a third party, but also in all other cases when the debtor entered into an agreement with the creditor that he could not conclude with the third party. For example, at the time of the pledge, the owner is obliged to transfer the property to the pledgee without the rights of third parties.

\section{REFERENCES}

1. Whittaker S. Comments on 'Abuse of Law' in European Private Law // Prohibition of Abuse of Law: A General Principle of EU Law? (= Studies of the Oxford Institute of European and Comparative Law. Vol. 13) / R. de la Feria, St. Vogenauer (eds.). Hart Pub., 2011. P. 253-261. 
Doi: https://doi.org/10.37547/tajpslc/Volume02Issue12-05

2. Basic provisions of civil law: article-byarticle commentary to articles $1-16.1$ of the Civil Code of the Russian Federation [Electronic edition. Revision 1.0]; A.G. Karapetov. - Moscow: M-Logos, 2020 .1469 p. P. 854.

3. Tserkovnikov M.A. On conscientiousness in the institutions of property law // Bulletin of civil law. 2017.Vol. 17.No. 2. P. 24-30.

4. Porotikova O.A. The problem of abuse of subjective civil law. $M$ : Walters Kluver, 2007. P. 182.

5. Digests of Justinian / Per. from lat. T. III. M .: Statut, 2003. P. 291.

6. Miller, P. B. (2011). A Theory of Fiduciary Liability. McGill Law Journal / Revue de droit de McGill, 56 (2), 235-288. https://doi.org/10.7202/1002367ar. 